\title{
Revisiting (inclusive) education in the postcolony
}

\author{
Hadiza Kere Abdulrahman, Foluke Adebisi, \\ Zibah Nwako and Elizabeth Walton
}

Abstract: This article uses a dialogic approach to explore the complex state of education in the postcolony. It revisits the subject of educational inclusion (and exclusion) and interrogates different epistemological and systemic framings of what constitutes education and knowledge, and the effects that these have on the postcolonial educational landscape. The authors ask troubling questions of the ways that the largely Eurocentric conceptualisations of these issues, and the baggage of colonial(ism/ity) can and do affect the design and delivery of education in these settings. The use of a metalogue as a methodological approach allows the contributors to jointly ponder the issues from different perspectives and positionalities, and in a way that honours their individual voices.

Keywords: Education, inclusive education, exclusion, knowledge, postcolony, colonial(ism/ity).

(C) The author(s) 2021. This is an open access article licensed under a

Creative Commons Attribution-NonCommercial-NoDerivs 4.0 Unported License 


\section{Introduction}

Education in postcolonial societies is complex and entangled with the past and present exercise of global power. Multiple, often competing, demands and influences shape education systems. One of the demands is for universal access to education, variously framed by the 'Education for All' and inclusive education initiatives. These are, in turn, imbricated with global discourses of 'development' and 'aid', and tend to offer an imaginary of access to Western-style classrooms and knowledge. The authors of this paper are concerned through dialogue to interrogate ways in which 'education' and 'inclusion' are often conceptualised within a Eurocentric framework. Mignolo (2002) states that it is no longer possible, or at least unproblematic to 'think' only from the canon of Western philosophy as to do this means to reproduce the blind epistemic ethnocentrism that makes difficult, if not impossible any political philosophy of inclusion. This contributes to what Ndlovu-Gatsheni (2013a) refers to as the rise of the decolonial epistemic perspective as a counter-hegemonic intellectual thought, questioning and challenging Euro-American epistemology's claims of being the only mode of knowing that is neutral, objective, disembodied, and universal. Within this framing, as authors we therefore acknowledge the continual need to revisit the meanings and purposes of education and their scope; especially in situations where people are working with thinking, and in contexts otherwise.

\section{Use of metalogue as an approach}

The idea of a metalogue, a 'dialogic' approach, and in this case a four-way conversation between the authors, came about from an acknowledgement of the conceptual and methodological complexities of this work and the value of diverse perspectives. It was originally intended as a panel discussion, and we are experimenting with a way to translate the immediacy of discussion and interaction of a panel (Allen 2017) into a written form in a way that doesn't collapse individual authorial contribution. The four authors come from different backgrounds and each uses a different lens to highlight (and instantiate) the forms that educational exclusion takes in various contexts. The contributions are intended as provocations, rather than quests for neat, definitive answers. We explore different framings that acknowledge layers, complexities, and legacies; and seek ways to construct new and transformational understandings of both education and inclusion.

The metalogue as an approach describes 'written conversations among parties that preserve individual voices while revealing contested areas - offering a method of inquiry for exploring the creation of scholarship' (Staller 2007: 137). This process embodies our different positionalities and expertise while also navigating differences. 
Metalogues allow co-authors to retain their personal and idiosyncratic voices rather than to sweep differences under the carpet of the fictional third person perspective (Tobin \& Roth 2002: 269). We expect this approach to reveal our doubts, thoughts, and convictions, but also the contentions and negotiations that may come along with exploring a topic such as this from different disciplines and positions.

All four contributors are African scholars but not necessarily 'scholars in Africa', and could be considered as what Nyamnjoh (2004) terms 'diasporic intellectuals'. We are aware that this constitutes an emerging space of global imagining, of belonging and of identification, and we seek to interrogate different epistemological perspectives and valorise alternative ways of being. Three of the contributors are originally from Nigeria, and one is from South Africa, finding value in 'critical conversations' (Walton 2015) across contexts that are linked by common experiences of (post)colonialism but are also very different.

The article starts off with Foluke Adebisi exploring the concept of education and knowledge. Foluke's scholarship focuses on decolonial thought in legal education. Her section explores how educational structures can depart from the true pursuit of knowledge as an egalitarian quest, dependent on what purposes those structures devote themselves to.

Elizabeth Walton follows, asking what it means to be working and thinking within multilayered contexts and framings of what constitutes inclusion and education. Her contribution draws on research in South Africa where the legacy of apartheid and colonisation complexifies the quest for more inclusive education.

Zibah Nwako's submission seeks clarification for what happens when the very concept of education is exclusionary, when it does not always take into cognisance marginal groups, alternative knowledge(s), and other forms of both schooling and education in the context of South-East Nigeria in West Africa. Zibah investigates the impact of informal learning on the aspirations and experiences of girls and women in rural Igboland. She approaches this topic through a postcolonial lens to enable a critical analysis of the current education system(s).

Hadiza Kere Abdulrahman ends with a scrutiny of what happens when the education system inherited through the colonial project is contrary to what some people want. She does this by looking at the case of the Almajiranci system of Qur'anic education in northern Nigeria. She considers the ways that the history and the current manifestation of 'Western education' encourage a form of educational exclusion, whereby the practitioners resist being included into this dominant and preferred form of schooling.

Following on from each author's contribution, the others engage with what has been written either in the form of observations and/or questions (in italics), in order to seek clarity, or to shed light from a different perspective. 


\section{Foluke on education and knowledge}

To determine what it means to be educated, especially from the perspective of legal education and the law in general, I suggest here that we must consider what knowledge has been used for and how that use arises from and impacts upon the relationship between person, education, and knowledge. It is also important to note how these uses are complicit in creating a hierarchy of humanity and the material consequences of the hierarchisation. The key questions that arise for me in this exploration include not just the purposes of education, but also the content of education - the purposes of education often dictate its content. Overlapping these two questions is the matter of inclusivity: that is, who/what is enclosed within the purposes and content of education? Whose meanings of reality are ultimately regarded as 'good knowledge'? How the preceding things interact with each is often affected by the historical and contemporary context within which education is happening - what state structures the educational system is embedded in, what trauma lives on in the earth, how the state sees itself, how the state is seen from outside, and what divisions exist within the state. How a state decides what education is, arises from an indeterminate mix of the foregoing.

It is generally accepted that education is meant to transmit knowledge and form part of the process of knowledge extraction and production. Therefore, knowledge is often considered to be a public good protected by the state and law-knowledge curation done right benefits the entire society; thus the state has a responsibility to provide. Alternatively, education could be considered a mere personalised by-product of knowledge curation. In this sense, education is primarily an individual or even consumer good; its purpose - self-betterment — not only a means of personal development but also career and therefore financial advancement. The law's role in this second meaning is not to prevent access to those able to afford it.

What role then does inclusion play in this? Inclusive education helps to bring in a variety of perspectives to enable us to unveil and confront pre-existing biases (Ansley 1991). However, without questioning why our education structures exclude, there is always the danger that people could be included into unchanged spaces that are not safe for them, spaces historically and repeatedly designed to harm and exclude them. To think more critically about inclusive education, we need to examine how the purposes and content of education interact with the purposes and processes of inclusion as well as how structures operate to exclude in multifaceted ways. For example, writing of South African society after apartheid, Morrow (2015) explored the ways in which disadvantage continued to be preserved in educational structures. He cited the ways in which historical permanence of structures of privilege within education, including the true beneficiaries of university funding models, result in institutional inability to respond to a broad range of social needs; institutions remain 
solely responsive to dictates of power (Morrow 2015). One wonders how education can serve the needs of the many, if it is inherently programmed to respond to power. Do educational structures still serve the purposes of education if they are inherently directed to preserve historical hierarchisations? Who is being educated and for what purposes?

\section{On knowing, being known, and education}

How a person is educated within a system is often predicated upon how knowledge has (mis)placed them within the system. Freire, hooks, and Fricker all explore the idea of knowledge, education, and being known, though from different perspectives. hooks' pedagogical philosophy is heavily influenced by her own experiences of school segregation and existing in educational spaces as a Black woman in the USA (hooks 2014). She suggests 'education as the practice of freedom' requires care in listeningto enable a validating exchange of experiences and knowledges (8).

Freire argued that education often functioned as a system of knowledge 'banking' passive collection and regurgitation (Freire 2000: 72). He said that 'liberating education consists in acts of cognition, not transferrals of information' (79). Because Freire believed that knowledge was a constantly evolving product of persistent human inquiry, he asserted that knowledge should change the world by transforming and empowering the participants in education: that is, they should not play pre-scripted roles in the process (Freire 2000).

What the educator does in teaching is to make it possible for the students to become themselves. And in doing that, he or she lives the experience of relating democratically as authority with the freedom of the students. (Horton et al. 1990: 181)

Freire (2000) argued that education had revolutionary capacities and could be used to bring about meaningful societal change. Fricker (2007) explains how injustice occurs because a particular group is unable to convey their experiential testimony to another (usually dominant) group. This inability is caused by the cognitive inability of the hearer-group to engage with the truth of the knower-group's social experience. Consequently, epistemic/hermeneutical injustice and marginalisation result because the knower-group's social condition is obscured from collective understanding (ibid). This is conceptually important to the process of inclusive education. Who decides how inclusion happens and whose voices get heard in the process? Fricker (2007) describes how social identity power can be used to silence, sometimes benevolently, sometimes passively, but mostly unjustly. She argues that the mere existence of social constructions of power serve to silence the subordinate group. The structure of society results in self-policing silencing activity. The classroom is revealed as an exclusionary 
site of power and knowledge exclusions. The role of the state/law and its perspective on education cannot be discounted in this process.

How then do we ensure that our pedagogy liberates through open dialogue, as Friere, Fricker, and hooks suggest, when this is impeded by the inability of the silenced to comprehend the nature of their silencing and oppression-hermeneutical injustice? (Fricker 2007). It is important to understand education as a societal good and not a consumer good. This is because a narrow and individualised understanding of the purposes of education has the potential to set education adrift from knowledge. Without entrenched understanding of knowledge as a constantly evolving product of persistent human inquiry, education reproduces exclusion. To reiterate, the role of the state/law cannot be discounted in a deliberate positioning of education as a public good.

Hadiza: The reference to the need to consider the historical and contemporary contexts within which education happens, especially asking us to consider the structures embedded in it and the trauma that lives on are what I find resonant. In my submission I allude to the effects of these as possible reasons why practitioners of the Almajiranci system of education find the dominant education unsuitable and choose to self-exclude. In Nigeria today, the education system is a key tool for the construction of social difference and reinforces a hierarchisation of human value and worth based on its acquisition. When the framing of an education system is based on 'epistemic disrespect', with alternative forms of knowing (and being) repeatedly subjugated, invalidated, and pushed to the fringes; attempts to include into it, only result in other forms of exclusion. To paraphrase you, the whole education system then becomes 'an exclusionary site of power and knowledge exclusion'.

Elizabeth: Foluke, each of the questions you pose is a necessary provocation, and you challenge simplistic notions of education as a panacea for the social, economic, and political challenges of postcolonial societies. I would like to amplify the point made about the potential for 'inclusive' education spaces to be harmful, because they are fundamentally designed to be exclusionary in various ways. It makes me think about the violence that is enacted on non-normative bodies, ideas, and ways of being, all in pursuit of 'including', as if inclusion into mainstream education is always and necessarily the greatest good for everyone. Perhaps we should listen more to those who, as Hadiza notes, choose to absent themselves from 'inclusive' schools.

Zibah: The references to Freire, hooks, and Fricker are a representation of my argument in promoting education as it should be, not as it currently is. hooks' idea of practising freedom extends to one's values of what constitutes knowledge from one's own experiences. 
Freire suggests that knowledge should both transform and empower rather than be prescriptive, denoting a preference for 'learning' and not 'schooling'. I go on to address these issues below. I would also apply Fricker's notion of injustice in my research context, given the inability of rural students to 'perform' as well as those in urban areas (the dominant group) and therefore are even more marginalised by an education system that places more attention (funding and expectations) on the latter - the dominant groupthereby ignoring the benefits and potential of the former.

Foluke: It is a kind of double-bind, especially concerning the role of the state. The state needs to listen to those who exclude themselves from these educational spaces, but also needs to provide education. One observation that has been made by many writers from the Latin American Decolonial School is that we need to think beyond the state as the primary organiser of political and juridical life. This raises all sorts of interesting logistic questions, but also questions of justice and freedom.

\section{Elizabeth on 'working with multilayered framings'}

International conventions and goals towards increased access and success in education validate ongoing concerns about the extent and impact of educational exclusion. They offer a vision of equity and inclusion that is expected to be shared across the world. The business of inclusive education is booming, with international attention to the cause that its advocates of decades ago could only have dreamed of. From the inspiration of the Salamanca Statement (UNESCO 1994) some twenty-five years ago, we now have the United Nations (UN) Convention on the Rights of Persons with Disabilities (CRPD), signed, if not ratified, by the majority of countries in the world (UN 2006). Article 24 of the CRPD concerns education and General Comment 4 on this article (UNESCO 2016) set out unequivocally what is meant and intended by inclusive education for children and young people with disabilities. The General Comment is said to be "the most comprehensive and authoritative international instrument explaining the human right to inclusive education' (Davis et al. 2020: 90). The Sustainable Development Goals (UN 2015) explicitly mention inclusive education in Goal 4 (although inclusive is often omitted when the goal is summarised as 'quality education for all') and, most recently, the Global Education Monitoring Report (GEMR) (UNESCO 2020) has focused on inclusion in education.

It has been said that inclusive education is contextually determined and will look different in different countries. This is valid, insofar as histories and geographies of exclusion will shape priorities and possibilities (Kamenopoulou 2020). But contextually determined inclusion potentially sanctions partial or conditional inclusion. As the 
GEMR (UNESCO 2020) shows, some versions of inclusive education replicate or reinvent exclusion, and policy does not always translate into the lived experience of vulnerable population cohorts. I think that there is value in critically evaluating different versions of inclusive education, recognising where limited or conditional iterations of inclusion fall short of its intended reach and impact. With this in mind, my contribution to the metalogue takes up a point I have made elsewhere: 'The pressure to adopt inclusive education comes with scant recognition of ways in which the history of colonialism and underdevelopment in countries of the Global South compound the problems of educational exclusion' (Walton 2018: 34). My focus is on South Africa, where up to half a million disabled children and young people are not in school, despite a policy commitment to inclusive education (Human Rights Watch 2015).

Realising the global policy ideals of inclusive education in local schools and classrooms has proved to be difficult. General Comment 4 offers several reasons for the non-implementation of inclusive education. These include the prevalence of a medical rather than social and human rights model of disability; discrimination; lack of knowledge about inclusive education; a lack of 'political will, technical knowledge, and capacity, including inadequate teacher education' (UNESCO 2016); and inadequate funding. Reasons found for the non-implementation of inclusive education in South Africa mirror those given in General Comment 4. Concerns have also been raised about the incompatibility between inclusive teaching practices and a fast-paced, content-heavy, and lock-stepped national curriculum (Andrews et al. 2019). This curriculum is seen as a mechanism by which learning outcomes (measured by national and international standardised tests) can be improved. Exclusion of those who do not meet the standards becomes a way to boost performance scores. There has also been resistance to Western formulations of inclusive education, perceived as an imposition from the Global North (Walton 2018). Accounting for non-implementation promises a direction for remediation, but education systems are not mechanical, functioning through direct lines of cause and effect.

Education systems are complex systems in themselves, constituted by a number of subsystems in dynamic and reciprocal relationships with each other. In turn, education and other domains (like the economy, civil society, etc) relate to each other in 'multi-causal and multi-directional' ways (Tikly 2020: 58). This is well illustrated in the GEMR concept note (UNESCO 2018: 5), which acknowledges six elements that constitute inclusive education: 'Laws and policies, governance and finance, school curricula, personnel, and infrastructure, and community norms, beliefs, and expectations'. While each of these elements warrant individual consideration for their contribution to inclusion (and exclusion) at local and systems level, it is clear that they are mutually constitutive and reciprocal. This means that educational exclusion 
in any context has to be recognised as a 'wicked problem' (Walton, 2017) that defies simplistic definition and resolution.

Colonial legacies are under-recognised as factors that complexify the challenge of bringing about more inclusive education in postcolonial contexts. In South Africa, the inequalities of the past persist, despite legislation and massive investment in personnel and infrastructure by the post-1994 government. At the broadest level, Fleisch (2007) characterises South Africa's education system as 'bimodal', comprising two 'systems'. The first is generally well functioning, made up mainly of former white and Indian schools, and independent schools, which together produce most of the country's university entrants. This is insulated from the second system, mostly serving poor learners from deprived communities, and which offers a 'restricted set of knowledge and skills' (2) compared with what is offered in the first system. The ongoing realities and results of these two systems perpetuate the inequities of the apartheid state.

Learners in richer, advantaged schools perform significantly better in reading and mathematics than their counterparts in poorer, non-advantaged schools. Resources in the advantaged schools promote learning and an environment conducive to learning. As a result of the apartheid prioritisation of white education, these schools have infrastructural resources like sports fields, libraries, media centres, toilet blocks, and electrification. As a result of their continued ability to charge fees (Taylor et al. 2013) and attract middle-class parents, these schools now have computer laboratories, WIFI, additional teachers to reduce class sizes, and the capacity to offer wider subject choices and extramural opportunities. By contrast, non-advantaged schools, as a result of the apartheid legacy of inadequate funding of black schools, often have inadequate and degraded facilities, and may lack basic amenities like toilets, electricity, and desks. There may be larger classes, which makes it difficult for teachers to attend to individual learners (Dieltiens et al. 2012). Van der Berg et al. (2011) report that there are significant differences in reading performance between the richest and poorest $20 \%$ of Grade Six learners. In terms of mathematics, Spaull (2015: 36) finds that, 'By grade 3, children in the poorest $60 \%$ of schools are already three years' worth of learning behind their wealthier peers and that this gap grows as they progress through school to the extent that, by grade 9, they are five years' worth of learning behind their wealthier peers.' The poor quality of education available in non-advantaged schools results in exclusion from life chances, including access to further or higher education and employment.

It is against this background that South Africa's policy on inclusive education is expected to be implemented. Outlined in White Paper Six (Department of Education 2001), an inclusive education system is envisaged to 'contribute to establishing a caring and humane society, how it must change to accommodate the full range of learning needs and the mechanisms that should be put in place' (11). The years since 
its promulgation have seen mixed responses, with pockets of good practice identified in individual schools (e.g. Walton 2011, Engelbrecht \& Muthukrishna 2019), but also evidence of large numbers of disabled children out-of-school (Human Rights Watch 2015). But mapping inclusive education onto a system fundamentally shaped by colonial and apartheid education is bound to have limited traction. The path dependencies of colonial and apartheid education persist (Tikly 2020). Inequitable outcomes linked to race, socio-economic status, and disability seem to be accepted as the inevitable consequence of a competitive system where only a few are advantaged. However, as I have argued previously (Walton 2018), inclusive education has the potential to disrupt colonial/apartheid hierarchies of value, given its demand for a radical transformation of education systems to offer equitable access, participation, and success to all. This requires that instead of inclusive education being wrangled to fit onto existing processes and structures, it is allowed to shape a new architecture of schooling for a postcolonial world.

Foluke: I am very interested in the way in which inequalities reproduce themselves, especially in contexts designated as postcolonial: that is, when the colonising force has removed itself from the immediate site of colonisation. I think universal legal instruments as well as international monitoring, both of which you mention Elizabeth, while inherently altruistic also inadvertently serve as a means to preserve colonial logics. On the one hand, this illustrates how what exponents of Latin American decolonial thought such as Walter Mignolo and Nelson Maldonado-Torres call 'coloniality', relies on a certain level of automation or systemisation. On the other hand, this enables us to understand that, in thinking of inclusivity in education and knowledge production/ transmission, change will require creative thinking. From a legal perspective, an example of creative thinking can be found in the jurisprudence of the Inter-American Court of Human Rights which has formulated and enforced the right to a 'project of life'. A right to harbour a 'project of life' has been described as a canopy approach that incorporates component rights (that is, combining both economic, social and cultural rights like the right to education, with civil and political rights like the right to life) based on the core idea of human dignity. The Inter-American court's jurisprudence reflects this in its 'Panchito López' $v$ Paraguay, judgement where it held that violating the right to education destroyed 'life plans/projects', thus violating the right to life. I suggest that is one way of thinking beyond rigid boundaries. But this also reminds me of Lewis Gordon's (2017) admonition on our ideas of justice, when he asks, 'What should we do if it is not only our conception of justice, but also the very notion of it, as the fundamental expectation with which to organize society, is also colonized? What if we are living in a world of "unjust justice" or "just injustice"?' I ask then, how do we make education more 
inclusive in our search for a better world, when we cannot imagine together what true inclusion looks like or how this better world would be organised?

Hadiza: The outline of the GEMR concept note with six elements that constitute inclusive education above with an emphasis on 'laws and policies' reminds me of the Nigerian context with Almajiranci, where successive governments have called for its ban and passed laws to that effect. I have argued elsewhere drawing from the Circuit of Culture (du Gay et al. 1997) that even the way that Almajiranci is regulated is affected by what we conceive of knowledge to be-which is heavily informed by coloniality. If we believe Almajiranci is not worthy and is incompatible with modernity, then a ban would be a quick-fix solution rather than investing in reform in line with community norms, belief, and expectations. The required curriculum change needed for a more inclusive education system would also be limited by these same constraints. The six elements more than being mutually constitutive and reciprocal, appear mutually opposing and incongruent, where one appears to be working against the others?

Zibah: Like you Elizabeth, I am concerned about the idea that inclusive education is context-based and relative to each country. In the case of Nigeria, for example, the only two parts of the National Policy for Education that address inclusion cover the areas of nomadic and special needs education (NERDC 2014). Within these two areas, the policy targets the 'first six years of Basic Education' for children of pastoralists, migrant fisher folk, and migrant farmers (22); as well as people with physical or learning disabilities. This leads me to question whether the national policy does not by itself exclude other groups of people (some of whom we have highlighted in this paper) from the formal, colonial education system, particularly if there is no other provision for their learning. Inevitably, this serves not only to perpetuate colonial legacies of power imbalances, but also leads to further disadvantage, marginalisation, and inequity in and through education systems.

Hadiza: Yes, the Nigerian education landscape is truly a site of several exclusions. It is still a long way off from comfortably including people with special educational needs and disability. Even where it has been addressed by policy, it remains a rhetoric and non-existent in practice.

Elizabeth: In response to your comments, I am reminded of Slee's (2011) first and second order questions in pursuing inclusive education. First, he says, we have to confront 'the power relations articulated through the structures, processes and culture of schooling' (157). Doing so prevents us from approaching inclusion as a compensatory 
measure for 'outsiders' or 'burdensome' children who remain tenants on the margins of unchanged institutions. Where inclusive education is shoehorned to fit 'nicely' into existing structures and practices, its insurrectionary potential is lost.

\section{Zibah on learning systems in precolonial contexts}

I start by problematising the purposes and terms of 'education' and 'inclusion' in relation to my study on the impact of informal learning on the aspirations and experiences of girls and women in rural Igboland, Nigeria. Using a postcolonial lens, I explore other forms of education, such as informal and non-formal learning, community and precolonial education, and indigenous knowledges within the research context. Drawing from Foluke's section, education is understood to be both a public good that benefits whole societies and for individual development and advancement. My first provocation therefore is: is the current education system fit-for-purpose, whether for societies or for individuals? Who benefits from it? Secondly, I intend to disrupt the dominant narrative of the high number of out-of-school children in the Global South especially Nigeria (UNICEF 2014), and the seemingly meaningful calls to increase access for women and girls to schooling and mainstream educational facilities (Aikman \& Unterhalter 2007, Fennell \& Arnot 2008, Iverson \& Nyamakanga 2012, Rao \& Sweetman 2014, UNESCO Institute for Statistics 2014). How about we reframe 'education' as 'learning' or 'knowledge(s)'? What do these terms mean or imply particularly for individuals and societies in the Global South?

\section{Education for all and for life}

With the ongoing debate about education as a human right and the United Nations Educational, Scientific and Cultural Organization's (UNESCO 1990) international directives on Education For All (EFA), it is insightful that proponents of other forms of learning have long submitted that formal education is no longer fit-for-purpose. According to Rogers (2004: 48-9),

The UNESCO Faure Report of 1972 provides a summary of many [of the] arguments. First, the formal system of education is not a natural, universal and inevitable model. It is something which grew up in a specific place (western Europe mainly) at a specific time (relatively late, in fact, during the second half of the nineteenth century) to meet a specific need (to discipline the populace for participation in an industrial society). Such schooling set out to train young persons for a lifetime of controlled work rather than self-determining activities. 
This argument raised several questions regarding the current provision of formal education in the Global South. In Nigeria, for instance, the system of teaching is by rote and, as indicated by Freire above, it is conducted as a transferral of information from teacher to student, rather than through critical thinking, experience, and senses. There are also pressures on pupils and students to 'pass' the termly and annual promotion examinations, and with oversubscribed places in higher education institutions, these all indicate that the formal education sector appears to lack holistic opportunities for an individual's own personal development.

According to the Organisation for Economic Co-operation and Development (OECD 2013: 11), 'education is for life, not for the classroom. Indeed, some of the most important skills for life and learning may be acquired before, after and outside school.' If the purpose of education is to acquire skills for life, and that these skills can be achieved outside the confines of schooling, is it not therefore important to pay attention to other different forms of learning (other than within schools)? Adeyemi and Adeyinka (2002) also consider derivations of the term 'education' from the Latin words educare (to bring up, rear, guide, direct) and educere (to draw out, lead out, raise up, bring up, rear a child). How, therefore, are these processes conceptualised and carried out within education typologies and systems?

\section{Types of education}

Coombs et al. (1973: 10-11) give seminal definitions of three forms of education: On the one hand, formal education refers to 'the hierarchical structured, chronologically graded 'educational system', running from primary school through to university and including, in addition to general academic studies, a variety of specialised programmes and institutions for full-time technical and professional training'. Non-formal education includes 'any organised educational activity outside the established formal system - whether operating separately or as an important feature of some broader activity - that is intended to serve identifiable learning clienteles and learning objectives' Informal education is, on the other hand, 'the truly lifelong process whereby every individual acquires attitudes, values, skills and knowledge from daily experience and the educative influences and resources in his or her environment - from family and neighbours, from work and play, from the market place, the library and the mass media'. From a wide range of literature and theories from both Western and nonWestern countries about the merits of non-formal and informal forms of learning, they have been known to add value to mainstream education and are used as an alternative to formal education in some contexts: for example, home-schooling (Guterson 1992, Thomas 2002, Houston \& Toma 2003, Romi \& Schmida 2009, Murphy 2014). However, gaps remain in the literature between formal or mainstream education and 
non-formal or informal learning within the African continent. Further, the current conceptualisation of education and formal schooling in Nigeria is largely considered to be Eurocentric and Westernised as it emerged from British colonial rule from 1900 to 1960 (Ocheni \& Nwankwo 2012).

\section{Who is excluded?}

Before addressing the importance of alternative learning and knowledge(s), I will consider the issue of marginal groups. In doing so, a pertinent question must be asked: Who does formal education/schooling include and who does it exclude? Some of the answers are pupils and students who are not seen as 'academic', do not perform well or attain their set targets. There are those who, as Foluke stated, are excluded because the available education spaces are unsafe or harmful to them. There are children and young people who are not in education, training, or employment, and those unable to access learning due to family pressures, poverty, etc. The United Nations Children's Fund (UNICEF 2014) reports that at 8.8 million, Nigeria has the highest number of children in the world who are out-of-school. In many (poorer) countries, education is still not free and as such is unaffordable for many families. Since Eurocentric/Western education seems to be upheld as the modern ideal, it begs the question of whether other forms of learning - for example non-formal, informal, and traditional-are not deemed important because they do not lead to qualifications? Which knowledge(s) is/ are therefore seen as important? As Crossley \& Watson (2003) also queried-is formal education the best way to reach the millions of people who currently have few or no opportunities to access it? I argue that for some of these young people, formal education presents a barrier to discovering their creativity and non-academic skills that are essential to their growth and progress in life. Several scholars have also acknowledged that the formal Western and Eurocentric education systems that were imposed on Nigerian citizens during colonial rule are considered to be strict, ineffectual, and unsuitable for learners, compared to precolonial forms of learning (Quaynor 2013, Pastor 2015, Olarewaju 2018); hence the call for a disruption to schooling as the norm.

\section{Alternative knowledge(s) and other forms of learning}

A large part of the decolonisation debate argues for the recognition of alternative knowledges and less of the 'othering' that applies as a dominant narrative in Western forms of education, including indigenous and Islamic education systems. This section focuses on precolonial, non-formal, and informal forms of learning within indigenous contexts. 
The educational situation in pre-colonial Nigeria was tribally controlled and could be described as continuous as adolescents were constantly being engaged in learning and adults were engaged in teaching and setting an example... The education systems in Nigeria before colonialism were not formal schools in line with European models but it was still powerful and influential in allowing societies to function and flourish and maintaining values to be respected and honoured. (Olarewaju 2018: 11-12)

Before the colonial era, value was placed on indigenous (otherwise known as community) knowledges passed through families and generations. These took the form of music, dance, and other arts, storytelling, trade, agriculture, religious instruction, production of goods and services, cultural values and norms, health practices, etc (ibid). Mkpa (2015) described that, depending on the area of expertise, the local young men were taught how to farm or make iron and traditional medicines; whereas for the young women, it was lighter farm duties such as weeding, hair weaving, and decoration, becoming a home-maker and cooking. Intellectual, social, and behavioural skills were taught to both men and women. Adults taught children how to respect others in society and used observational situations and practical activities to prepare them for life (Olarewaju 2018). These ways of learning align with the above-mentioned definition of informal education as 'attitudes, values, skills and knowledge from daily experience and the educative influences and resources in [someone's] environmentfrom family and neighbours, from work and play, from the market place ...' (Coombes 1973: 11).

As previously mentioned, my study was in a small rural town in the South-East Nigeria (Nwako 2015). The participants were female secondary school students who are part of the most disadvantaged and marginalised groups within the research context:

In Nigeria, the average poor rural female is just above the two-year threshold for extreme education deprivation, with less than $40 \%$ the national average for years of school and around one-quarter the average for rich urban males.... The Nigerian case powerfully illustrates the mutually reinforcing effects of poverty, rural location and cultural factors in creating extreme disadvantage. (EFA Global Monitoring Report [UNESCO 2010: 142, 143])

I also interacted with women who provided narratives of their childhood learning experiences in rural towns. The main research question explored the ways in which young female students learn informally: that is, outside the confines of modern/(post) colonial mainstream education and formal schooling. The participants benefitted from traditional and community activities, such as festivals, traditional stories, songs, and family histories. They developed hobbies and interests in singing and dancing; learnt behaviours and attitudes including respect, responsibility, morals, hard work, self-confidence, and critical thinking; and acquired vocational skills ranging from 
traditional bead making, cooking and baking, sewing, hair plaiting, and making toiletry products.

These outputs highlight the similarities between informal traditional forms of learning and the valuable precolonial community and indigenous knowledges, and the importance of both in the argument for inclusive education. As a result, I present a final provocation: Is a readjustment of education structures necessary to acknowledge alternative ways of learning that are as, if not more, important as formal schooling in the Global South? Should we consider more democratic, autonomous, and Freirean forms of knowledge acquisition that are relevant to our societies and structures? Where, when, and to whom do these discourses apply?

Elizabeth: This section draws my attention to how porous the boundaries between formal, informa,l and non-formal education can be, or should be. Educational responses to the COVID-19 pandemic suggest that in many contexts we have witnessed a great deal of boundary crossing, as formal education has entered the private (in/non-formal) educational space of the home through remote teaching, and online and distance learning. The strong classification (cf. Bernstein 2000: 104) between the family context and the school context has been weakened, raising new questions about how school and everyday knowledge relate to each other (Young 2009). There has also been a disruption to assumed hierarchies of different types of education, knowledge, and learning. I am not proposing a new hierarchy of importance, but think that Boaventura De Sousa Santos's (2014) idea of an ecology of knowledges can be helpful. I like the metaphor of an ecology, because it talks of symbiosis, of different parts valued for their contribution because they are necessary, but not necessarily sufficient on their own.

Zibah: Your example of boundary crossing using the COVID-19 situation is aptly put. Home-schooling has become part of life for many families and it would be interesting to see if this makes any difference to future numbers of children registered in formal schooling environments. I will read De Sousa Santos's piece on the ecology of knowledges as it sounds like it could be considered as one of the ways forward for educational systems in the postcolony. I would also acknowledge here that the claim for alternative forms of learning, teaching, or education, including the suggestion of a hybrid of indigenous knowledges and Western education, is not exclusive to Nigeria. It has been highlighted in other Southern educational or political contexts in SubSaharan Africa, South Asia, and the Freirean-based forms of popular education in Latin America (Mazzer Barroso 2002, Banda 2008, Rao \& Hossain 2012).

Foluke: There are two questions that occur to me from reading this. The first is about the current nature of precolonial informal education. In other words, how has what used to 
be precolonial education evolved and what is it now? The second question is more logistic and political - how exactly do we readjust the current formalised education structures to acknowledge alternative knowledge production structures? I think with the first question I am concerned that our focus on the precolonial as a discrete timeframe means that we accede to the temporal colonial trick of misidentifying people inhabiting colonial territories as belonging to a time prior to the one that the coloniser existed in. The spirit of that misidentification lives on in the development narrative and education's place in that. Nevertheless, the informal knowledge production systems that you mention-soap and bead-making, for example-continued through colonial times and still exist, though greatly deprived of their prior importance to society. It is only by placing them outside of time, as it were, that we are able to make the developmental narrative fit. Secondly, the logistic question. This is related to the place that informal education used to hold in society. I fear that the nature of postcolonial states and their status in a global capitalist world provides little incentive to policymakers to readjust the education systems to primarily benefit the citizens in this manner. Thus, the developmental narrative masquerades as escape when it is a prison.

Zibah: I would offer a partial answer to your first question, Foluke, regarding what precolonial education is now - as may also categorise it as a form of 'vocational' education (in keeping with the examples of soap and bead making activities). However, vocational education does not adequately describe the richness and depth of learning that is offered and can be gained from African indigenous systems of knowledge.

Hadiza: Disrupting the framing of education and challenging the narrative of 'out-ofschool' children are approaches that I employ in my encounter with an alternative knowledge system. Your work with rural young women in Nigeria highlights the relevance of having a learning system that is a reflection of the society it is situated in, one that addresses their needs and concerns rather than attempting to shoehorn conceptions and delivery of education into a borrowed model. As a possible answer to your final provocation, I think that the adjustment of what is considered as formal schooling in the postcolony is a necessary step in addressing its lingering education problems. The inability to define education on our own terms and to our own needs has long complicated the process of its delivery and efficacy.

Zibah: Yes, it is important that policymakers and decision-makers in Nigerian national, state, and local governments understand that the hegemonic, one-size-fitsall forms of education is detrimental to the end-users and beneficiaries of such systems. It is therefore essential that attention be given to reassessing, and even disrupting, 
current systems in order to improve them in terms of both quality (of content and opportunity) and quantity (reaching 'out-of-school' populations).

\section{Hadiza on reasons for 'self-exclusion'}

The concept of inclusion (and exclusion) into education, and the several ways that these (can) occur trouble me. In this paper I argue that in order to recognise the nature of educational ex/inclusion, we need to revisit the understanding and forms of education and school(ing) in different contexts. What exactly are people excluding themselves from, and what are they are being included into? The phrase 'inclusion into what', borrowed from Allan (2007) cited in Walton (2018), forces the recognition of the practices and cultures of schools that result in marginalisation and exclusion. This phrase, Walton states, challenges renditions of inclusive education that are merely concerned with access to existing schooling without addressing the 'architecture of inequality and exclusion' on which education is built (Slee 2011). In the context of Northern Nigeria, Almajiranci, a classical form of Qur'anic education that sees young boys sent to study the Qur'an under the tutelage of a malam (teacher), is often regarded as problematic and retrograde and no longer suitable for the creation of the 'modern' Nigerian citizenry. It accounts for an estimated 7-10 million boys considered as out-of-school (Taiwo 2013, Antoninis 2014).

My previous research (Abdulrahman 2018), focuses on former almajirai (male students of the system), men who have been through the Almajiranci system specifically; situating the contentious mainstream representational discourses of Almajiranci education and knowledge that exist in Nigeria today as a meaning-making issue, one that has been influenced by a number of factors including modernity and coloniality. Coloniality here refers to long-standing patterns of power that emerged from colonialism, and it is therefore quite different from colonialism. Coloniality of knowledge especially addresses epistemological questions of how colonial modernity has interfered with other ways of knowing, social meaning-making, imagining, and seeing (Ndlovu-Gatsheni 2013b), especially in the case of formerly colonised people. It therefore makes sense that understandings of what education means and is to different people, would be affected by this.

Here, I explore two reasons why 'Western education' in Nigeria might not be the suitable choice for many. The first is that in Nigeria today, what is known as 'Western education' has been inherited through the colonial project with Nigeria being a former British colony (between 1900 and 1960). In this context it is therefore secular and based on an Anglo-European epistemology and conceptions of knowledge. It is also considered 'modern' and progressive and remains the dominant and favoured 
form of schooling, especially regarded as superior by many Western-educated Nigerians - who make up the ruling elite. Western education was first encountered in the North through the proselytising mission schools and it is against this backdrop that the Almajiranci system of education exists and is compared, often unfavourably. Highly politicised, Almajiranci evokes much passion from many Nigerians, and the boys and men who are educated through it are repeatedly subject to various negative (mis)representations and often regarded as a problem (Aghedo \& Eke 2013), mainly because of its most prominent feature of sending young boys away from home to live with a teacher. When they are not learning the Qur'an, the young almajirai can often be found begging on the streets or labouring for sustenance, which again causes a huge social concern especially for the welfare and rights of the boys.

\section{Understanding exclusion through revisiting the history of education in Northern Nigeria}

Education in Northern Nigeria is peculiar historically in many ways compared to the rest of Nigeria. Hansen and Musa (2013) state that, when the colonial wave reached the North in the late 19th century, it was met by long-established Islamic societies far better equipped culturally to resist the foreign influences. Western ways, including education they add, made more headway among the Southerners than in the North. This resistance continues until today through the Almajiranci system, and these Qur'anic schools have often operated as separate entities at cross-purposes with the Nigerian state in the provision of education for the millions of Muslim children who are described as 'out-of-school' (Baba 2014: 4).

Prior to colonialism also, Almajiranci primarily fed the system of administration of Northern Nigeria, with ajami (local languages written using modified Arabic alphabets) serving as a regional vehicle of communication for literature, poetry, commentary, and personal communication (Hansen \& Musa 2013). It is important to understand that Islam came into Northern Nigeria in the early 14th century and became an established way of life with the Almajiranci system originating around the 16th century (Bano 2009), encouraged and supported in urban centres in order to spread literacy. The British occupation of the territory divested Muslim scholars of nearly all their roles and influence (Khalid 2012).Many of the existing structures were abolished and new measures introduced that invalidated the otherwise thriving system. This overview of the system's encounter with colonialism is necessary as it situates it within a deeper social context - the longue durée if you will.

The parents of almajirai are largely rural Northern Nigerian masses, not 'Westerneducated' and sometimes harbouring a deep suspicion of Western education; especially given its history and the nature of its advent in the region. The fear for these religious 
and traditional parents is that their children will be converted to Christianity or adopt alienating ways. Many of the fathers (being former almajirai themselves) value the Almajiranci form of education, seeing it as the best that they can offer their children given their material circumstances. Sule-Kano (2008) talks about the 'glory days' of Almajiranci which offered the 'peasant' or 'talaka' one of the few routes for achieving upward mobility. Sadly, though, this is no longer the case: to be an almajiri in Nigeria today is to be disenfranchised especially from the perquisites of power. What this means is that for many of these rural poor for whom Almajiranci is still the option, it presents a form of exclusion from the Nigerian dream; and where they have been co-opted into Western education - through various so-called integrative initiatives, it has been problematic and riddled with other forms of exclusion - which is the second reason why the 'modern' form of education might not be desirable to many.

\section{From 'out-of-school' to 'in-school'-including into what exactly?}

Almajirai are categorised as 'out-of-school' children and they make up the highest percentage of this category, $17 \%$ of the global 'out-of-school' population are believed to be living in Nigeria (Antoninis 2014). Since they exist out of the purview of the state, the clamour is to integrate the Almajiri schools, or to get the boys into Westernstyle public schools; especially as it is considered that any form of education would be better than Almajiranci. The public schools, however, have become a last resort for those without alternatives, with their poor quality often acting as a disincentive to school attendance. They are riddled with poor infrastructure, poor teacher quality and supply, poor learning outcome, and poor delivery (USAID 2003). So, while the Nigerian elite searches for alternatives in fee-paying private schools, the marginalised urban and rural poor either have no other choice or rely on the traditional Qur'anic schools instead. So much so that by the late 1990s, these Qur'anic schools commanded more pupil enrolment than the formal/public primary schools in many Northern Nigerian States (USAID 2003).

The quality of education available to many ordinary Nigerians frames the question of 'including into what exactly'. As Brenner (2001) points out, the promise of quality 'education for all' in postcolonial African societies has never really been fulfilled. In reality, many African countries grapple with social inequalities partly created through a form of schooling that has lacked quality and failed to reach 'all'. The very skills that 'Western-style schools' transmit, Brenner argues, have become symbols of political and social difference. In Nigeria today, the alternative to Almajiranci is a failing public schooling system (Baba 2011), a national educational system fraught with problems, including overcrowded classrooms, ill-trained staff, dilapidated facilities, inadequate resources, inconvenient hours of operation, unaffordable expenses 
(Antoninis 2014), alienating rules and regulations (Baba 2014), and an overloaded curriculum that holds little relevance, meaning, or purpose. Hoechner (2018) observes that, in a context where access to prestigious knowledge is stratified, many almajirai have also struggled to access 'modern' education that is affordable and of acceptable quality. The current education system has produced many graduates all waiting for promised government jobs that do not exist. It is also an educational system that produces graduates sometimes ill adapted to the African condition and market (Nyamnjoh 2004). Many postcolonial nation-states of Africa, after years of postcolonial history, have not shown a substantial improvement in the lives of young people (Abbink 2005). This demonstrates that the current form of education has had arguable, often contested, effects on the lives of many of the continent's young people in terms of what it promises to deliver, aligning with what Adebisi (2016) calls educational incompatibility - the inability of education to equip its citizens to fit in with and benefit the society they live in. Nigeria's middle and upper classes knowing the state of Nigerian public schools have opted out of it, paying for private education for their children instead, often seeking international pathways to qualifications that the masses cannot afford. Thus, the current educational landscape further stratifies and entrenches systemic inequalities. Education in Nigeria today hardly guarantees alternative routes for more than just a select few in a closed system of social reproduction, never mind it being a viable option for inclusion.

The above is the 'non-choice' for many of the practitioners of AlmajiranciWestern secular schooling, which they can ill afford and do not really want, with its minimal returns, opportunity costs, and alienating culture; or Almajiranci, which aligns deeply with their values and ways of life but which has fallen out of favour amongst many Nigerians for whom it is no longer seen either as valid or valuable. Either choice presents with its own form of exclusion in the postcolonial Nigerian society.

Foluke: Reading your section, I recall the words of Martin Luther King Jr, when he says, 'I fear I am integrating my people into a burning house.' I think this is reflected in the false distinction between the socio-economic and the political. Education as a human right, for example, is often considered an economic, social, or cultural right rather than a civil and political one. But I think your discussion of Almajiranci highlights that all socio-economic questions have civil and political implications and vice versa. What are we asking people to be included into when we advocate colonially imposed education as the path to personal development? What are nations being included into when they abandon historical and contemporaneous forms of non-formal and informal education? What nations are we trying to build? As bell hooks suggests, education should be the practice of freedom. I fear that there is no freedom to be found for either nation or 
citizenry, when the template aspired to, is imported. I think the paradoxes which Elizabeth mentions earlier and below are also relevant here. How do we give the people what they want, when to do so will deprive them of other things that they are entitled to?

Hadiza: Exactly, especially when the current state of Almajiranci poses serious children's rights concerns and is also not fit-for-purpose for various other reasons; when its continued existence in its current state, presents a real danger to some of its vulnerable practitioners, and perpetuates their marginalisation and exclusion.

Elizabeth: Hadiza, your provocation challenges the idea that there is a universally ideal model of schooling andlor education, that somehow is able to transcend all our differences and offer inclusion to all. You make a clear argument for why parents would choose Almajiranci in the Nigerian context. It also made me think of parents of disabled children who 'choose' special schools or home education, unwilling to expose their children to the conditions of mainstream schooling. There's another inclusion paradox here: Without the presence of the disabled/religious/raciall'Other', there is no need or impetus for schools or other education institutions to change, hegemonic norms continue unchallenged, and the status quo is increasingly normalised. But, what risk, what 'burning' (Foluke), what silencing must the 'Other' endure in these untransformed educational spaces?

Hadiza: Coming into inclusive education, this has been another realisation too: the increasing awareness that there really is no, and might never be, a 'universally ideal model of schooling' that is able to transcend these differences. In complex multicultural contexts like Nigeria, aiming for this ideal is near impossible. Add into this mix the awareness that what is considered as ideal is also deeply 'corrupted' by our history of colonialism and the present global power structure.

Zibah: I am intrigued by your conceptualisations of coloniality vs colonialism - as I understand it, by the former referring to the power structures that still dominate in societies that have been subject to the latter? Your explanation of the Almajiranci system as highly politicised and misunderstood certainly rings true in my experience. Coming from the South of Nigeria where the dominant, extremely misleading representation of almajiris is mainly negative and derogatory (for example, calling the boys and men beggars, mallams, aboki [stupid], jobless, thieves, etc), I now realise how important and relevant your study is, not only to scholarship but also to changing the understanding and mindset of the ordinary citizen in the South on the educational choices made by others like themselves. This change is particularly important as calls increase for a return to precolonial educational systems as I suggest in my final provocation. It would be 
interesting to find out how the categorisation of out-of-school children is spread across Nigeria and if the Almajiranci system is approved as an education system, how much it will affect the high numbers determined by UNICEF (2014). When a demographic (of people) chooses to exclude themselves from a formal, colonial education, preferring instead to encourage and practise their own form of learning, it behoves policymakers and scholars to investigate and reconsider the effects of this decision rather than label it as contrary to the status quo. Perhaps this will prompt internationallglobal resistance to the hegemonic norms and ideas of Western education beyond the Global South, particularly for similar postcolonial countries.

Hadiza: Using coloniality here is deliberate, it concerns itself with the effects of colonialism (long after it is considered officially over) on knowledge, being, and power. I am particularly interested in the ways it functions on 'our psyche' as formerly colonised people and its limiting effects on what we can think and do. The views of almajirai that you shared are common across Nigeria and make up what I call the mainstream representational discourses. Recently, almajirai have also been seen as members of the terrorist group Boko Haram, with their Qur'anic education regarded as a radicalising influence. I have previously used Hall (2013) to argue that the way you represent people goes on to determine how you treat them. These discourses 'other' almajirai and are harmful and particularly detrimental to their treatment both by the government (in their policies) and by individuals (in the everyday) and reinforce their exclusion.

\section{Conclusion}

The arguments presented in this paper would be recognisable in many postcolonial societies struggling to make their education systems fit and work better. Foluke argues that the purpose and content of knowledge, and how these interact, are affected by the historical and contemporary context within which education takes place. Zibah's questioning of types of schooling, especially formal schooling and its exclusionary potential, allows her to interrogate education in contexts such as Nigeria. Her question of whether it is fit-for-purpose and who it benefits is partly answered from Hadiza's study, which shows that some people 'choose' not to be included for reasons both historical and contemporary. For the practitioners of Almajiranci, Western education comes with both cultural and historical baggage; and is hardly fit-forpurpose due to systemic and epistemic inadequacies. Elizabeth's assertion is that different versions of inclusive education need to be critically evaluated with a recognition of their limitations. She highlights that the adoption of inclusive education 
hardly recognises the history of colonialism and underdevelopment in countries of the Global South. What is clear from all the contributions is a need to recognise the historical and contemporary complexity of the various contexts in which inclusive education has to be implemented.

Education in Africa must respond to the particular issues and challenges of the continent. The promotion of educational rights by international bodies has been focused mainly on improving availability and accessibility of education with African indigenous knowledge(s) rarely featuring in the process (Adebisi 2016). A process of continuous and persistent critical engagement with and selective incorporation of African knowledge (precolonial or postcolonial) is needed, while simultaneously resisting the lure of the institutive ascription of inferiority to different systems of knowledge (Handel Kashope Wright 2007, cited in Adebisi 2016). The contributions to this metalogue point to the intractability of some of the educational challenges of the continent, including patterns of exclusion that defy simplistic definition and resolution. In the absence of neat answers or trite recommendations, we argue for ongoing difficult and critical conversations, across contexts and across disciplines.

\section{References}

Abbink, G.J. (2008), 'Being Young in Africa: The Politics of Despair and Renewal', in J. Abbink \& I. van Kessel (eds) Vanguard or Vandals: Youth, Politics and Conflict in Africa (African Dynamics, 4; Leiden and Boston, MA, Brill Academic Publishers), 1-33.

Abdulrahman, H.K. (2018), "The Men They Become"-Northern Nigeria's Former Almajirai: Analysing Representational Discourses of Identity, Knowledge and Education', PhD thesis, University of Lincoln.

Adebisi, F.I. (2016), 'Decolonising Education in Africa: Implementing the Right to Education by Re-appropriating Culture and Indigeneity', Northern Ireland Legal Quarterly, 67(4): 433-51.

Adeyemi, M.B. \& Adeyinka, A.A. (2002), 'Some Key Issues of African Traditional Education', McGill Journal of Education, 37(2): 223-40.

Aghedo, I. \& Eke, S.J. (2013), 'From Alms to Arms: The Almajiri Phenomenon and Internal Security in Northern Nigeria', The Korean Journal of Policy Studies, 28: 97-123.

Aikman, S. \& Unterhalter, E. (2007), Practising Gender Equality in Education (Oxford, Oxfam GB). https://doi.org/10.3362/9780855988340

Allen, M. (2017), The SAGE Encyclopedia of Communication Research Methods (Thousand Oaks, CA, Sage). https://doi.org/10.4135/9781483381411

Andrews, D., Walton, E. \& Osman, R. (2019), 'Constraints to the Implementation of Inclusive Teaching: A Cultural Historical Activity Theory Approach', International Journal of Inclusive Education. https://doi.org/10.1080/13603116.2019.1620880

Ansley, F.L. (1991), 'Race and the Core Curriculum in Legal Education', California Law Review, 79: 1511. https://doi.org/10.2307/3480779

Antoninis, M. (2014), 'Tackling the Largest Global Education Challenge? Secular and Religious Education in Northern Nigeria', World Development, 59: 82-92.

https://doi.org/10.1016/j.worlddev.2014.01.017 
Baba, N.M. (2011), 'Islamic Schools, the Ulama, and the State in the Educational Development of Northern Nigeria', Bulletin de l'APAD, 33: 1-16. https://doi.org/10.4000/apad.4092

Baba, N.M. (2014), 'Qur'anic Education, The State and Islamic Militancy in Northern Nigeria: A Reassessment', paper presented at 10th Biennial Conference organised by World Council of Curriculum Instruction held at IBB University.

Banda, D. (2008), "Education for All (EFA) and "African Indigenous Knowledge Systems (AIKS)": The Case of the Chewa People of Zambia', PhD thesis, University of Nottingham.

Bano, M. (2009), Engaged Yet Disengaged: Islamic Schools and the State in Kano, Nigeria (Religions and Development Research Programme, Working Paper 29; University of Birmingham).

http://www.religionsanddevelopment.org/files/resourcesmodule/@random454f80f60b3f4/ 1256735712_working_paper_29.pdf

Bernstein, B. (2000), Pedagogy, Symbolic Control and Identity (Lanham, MD, Rowman \& Littlefield).

Brenner, L. (2001), Controlling Knowledge, Religion, Power and Schooling in a West African Society (Bloomington, IN, Indiana University Press).

Coombs, P.H., Prosser, C. \& Ahmed, M. (1973), New Paths to Learning for Rural Children and Youth (New York, International Council for Educational Development).

Crossley, M. \& Watson, K. (2003), Comparative and International Research in Education. Globalisation, Context and Difference (London and New York, Routledge).

Davis, J., Gillet-Swan, J., Graham, L. \& Malaquias, C. (2020), 'Inclusive Education as a Human Right', in L.J. Graham (ed.) Inclusive Education for the 21st Century (Crow's Nest, Allen \& Unwin), 7-99. https://doi.org/10.4324/9781003116073-6

Department of Education (South Africa) (2001), White Paper Six: Special Needs Education (Pretoria, Government Printers). https://www.gov.za/sites/default/files/gcis_document/201409/educ61.pdf

Dieltiens, V., Letsatsi, S., Ngwenya, E. \& Motala, S. (2012), 'Inside the School Gates: What Do Learners Have Access to?', in S. Motala, V. Dieltiens \& Y. Sayed (eds) Finding Place and Keeping Pace (Cape Town, HSRC Press), 72-86.

Du Gay, P., Hall, S., Janes, L., Mackay, H. \& Negus, K. (1997), Doing Cultural Studies: The Study of the Sony Walkman (London, Sage).

Engelbrecht, P. \& Muthukrishna, N. (2019), 'Inclusive Education as a Localised Project in Complex Contexts: A South African Case Study', Southern African Review of Education, 25(1): 107-24.

Fennell, S. \& Arnot, M. (2008), Gender Education and Equality in a Global Context: Conceptual Frameworks and Policy Perspectives (Abingdon, Routledge). https://doi.org/10.4324/9780203939598

Fleisch, B. (2007), Primary Education in Crisis (Cape Town, Juta).

Freire, P. (2000), Pedagogy of the Oppressed, trans. Myra Bergman Ramos (New York, Continuum).

Fricker, M. (2007), Epistemic Injustice: Power and the Ethics of Knowing (Oxford, Oxford University Press). https://doi.org/10.1093/acprof:oso/9780198237907.001.0001

Gordon, L. (2017) 'Decolonization Matters', Rowman \& Littlefield International Blog, 4 November, https://www.rowmaninternational.com/blog/decolonization-matters.

Guterson, D. (1992), Family Matters: Why Home Schooling Makes Sense (San Diego, CA, Harcourt, Brace).

Hall, S. (2013), 'The Work of Representation', in S. Hall, J. Evans \& S. Nixon (eds) Representation, 2nd edn (London, Sage), 1-59.

Hansen, W.H. \& Musa, U.A. (2013), 'Fanon, the Wretched and Boko Haram', Journal of Asian and African Studies, 48(3): 281-96. https://doi.org/10.1177/0021909612467277

Hoechner, H (2018), Quranic Schools in Northern Nigeria: Everyday Experiences of Youth, Faith, and Poverty (Cambridge, Cambridge University Press). https://doi.org/10.1017/9781108348270

hooks, bell (2014), Teaching to Transgress (New York, Routledge). https://doi.org/10.4324/9780203700280 
Horton, M., Freire, P., Bell, B. \& Gaventa, J. (1990), We Make the Road by Walking: Conversations on Education and Social Change (Philadelphia, PA, Temple University Press).

Houston, R. \& Toma, E. (2003), 'Home Schooling: An Alternative School Choice', Southern Economic Journal, 69: 920-35. https://doi.org/10.2307/1061658

Human Rights Watch (2015), 'Complicit in Exclusion'. https://www.hrw.org/report/2015/08/18/complicitexclusion/south-africas-failure-guarantee-inclusive-education-children

Iverson, E. \& Nyamakanga, R. (2012), 'Because I am a Girl: Africa Report 2012, Progress and Obstacles to Girls' Education in Africa', Plan West Africa Regional Office (WARO).

Kamenopoulou, L. (2020), 'Decolonising Inclusive Education: An Example from a Research in Colombia', Disability and the Global South. https://disabilityglobalsouth.files.wordpress.com/2020/05/07_01_01.pdf

Khalid, S. (2012), 'Crisis in Muslim Education: The Almajiranci System in Northern Nigeria and Response of State and Civil Society', paper presented at the 10th annual ITSR International Conference, Siena, Italy.

Mazzer Barroso, M. (2002), 'Reading Freire's Words: Are Freire's Ideas Applicable to Southern NGOs?' (International Working Paper Series 11; London, Centre for Civil Society, London School of Economics and Political Science) .

Mignolo, W.D. (2002), 'The Geopolitics of Knowledge and the Colonial Difference', The South Atlantic Quarterly, 101(1): 57-96. https://doi.org/10.1215/00382876-101-1-57

Mkpa, M.A. (2013), 'Overview of Educational Development: Pre-colonial to Present Day'. https://onlinenigeria.com/education/?blurb=534\#ixzz3ThN2UCnS

Morrow, W. (2015), Bounds of Democracy: Epistemological Access in Higher Education (Cape Town, HSRC Press).

Murphy, J. (2014), 'The Social and Educational Outcomes of Homeschooling', Sociological Spectrum, 34(3): 244-72. https://doi.org/10.1080/02732173.2014.895640

Ndlovu-Gatsheni, S.J. (2013), 'The Entrapment of Africa Within the Global Colonial Matrices of Power: Eurocentrism, Coloniality and Deimperialization in the Twenty-first Century', Journal of Developing Societies, 29(4): 331-53. https://doi.org/10.1177/0169796X13503195

Ndlovu-Gatsheni, S.J. (2013), 'Coloniality of Power in Postcolonial Africa, Myths of Decolonization' (Dakar, Council for the Development of Social Science Research in Africa).

NERDC (Nigerian Educational Research and Development Council) (2014), National Policy on Education, 6th edn (Lagos, NERDC Press).

Nwako, H. (2015), 'The Impact of Informal Learning on the Aspirations and Experiences of Girls in Rural Igboland of Nigeria', Master's dissertation, University of Bristol.

Nyamnjoh, F.B. (2004), 'A Relevant Education for African Development-Some Epistemological Considerations', Africa Development, 24(1): 161-84. https://doi.org/10.4314/ad.v29i1.22190

Ocheni, S. \& Nwankwo, B.C. (2012), 'Analysis of Colonialism and Its Impact in Africa', Cross-Cultural Communication, 8(3): 46-54.

Olarewaju, H. (2018), 'A Postcolonial Analysis of British Colonialisms Effect on Nigeria's Education System', Master's dissertation, University of Bristol.

OECD (Organisation for Economic Co-operation and Development) (2013), Education Today: The OECD Perspective (Paris, OECD Publishing).

Pastor, J. (2015), 'Post-development Theory: What is Education For?', in T. McCowan \& E. Unterhalter (eds) Education and International Development: An Introduction (London, Bloomsbury).

Quaynor, L. (2013), 'Youth Activism in Out-of-school Contexts: Atai Shops and the Intellectual Forum in Liberia', paper presented at the Northeast Regional Meeting of the Comparative and International Education Society, Amherst. 
Rao, N. \& Hossain, M. I. (2012), “'I Want to Be Respected”: Migration, Mobility, and the Construction of Alternate Educational Discourses in Rural Bangladesh', Anthropology \& Education Quarterly, 43(4): 415-28. https://doi.org/10.1111/j.1548-1492.2012.01194.x

Rao, N. \& Sweetman, C. (2014), 'Introduction to Gender and Education', Gender and Development, 22(1): 1-12. https://doi.org/10.1080/13552074.2014.902230

Rogers, A. (2004), Non-formal Education: Flexible Schooling or Participatory Education? (Hong Kong, Comparative Education Research Centre). https://doi.org/10.1007/0-387-28693-4

Romi, S. \& Schmida, M. (2009), 'Non-formal Education: A Major Educational Force in the Postmodern Era', Cambridge Journal of Education, 39(2): 257-73.

https://doi.org/10.1080/03057640902904472

Santos, B. de S. (2014), Epistemologies of the South (Abingdon, Routledge).

Slee, R. (2011), The Irregular School: Exclusion, Schooling and Inclusive Education (Abingdon, Routledge). https://doi.org/10.4324/9780203831564

Spaull, N. (2015), 'Schooling in South Africa: How Low-quality Education Becomes a Poverty Trap', South African Child Gauge, 12: 34-41.

Staller, K. (2007), 'Metalogue as Methodology: Inquiries in Conversation among Authors, Editors and Referees', Qualitative Social Work, 6(2): 137-57. https://doi.org/10.1177/1473325007077236

Sule-Kano, A. (2008), 'Poverty and the Traditional Qur'anic School System in Northern Nigeria: The Politics of the Almajiri-Phenomenon', paper presented at Conference on Nigerian Youth.

Taiwo, F.J. (2013), 'Transforming the Almajiri Education for the Benefit of the Nigerian Society', Journal of Educational and Social Research, 3(9): 67-72. https://doi.org/10.5901/jesr.2013.v3n9p67

Taylor, N., van der Berg, S. \& Mabogoane, T. (2013), 'Context, Theory, Design', in N. Taylor, S. van der Berg \& T. Mabogoane (eds), Creating Effective Schools (Cape Town, Pearson), 1-30.

Thomas, A. (2002), 'Informal Learning, Home Education and Homeschooling', in The Encyclopaedia of Informal Education.

http://infed.org/mobi/informal-learninghome-education-and-homeschooling-home-schooling/

Tikly, L. (2020), Education for Sustainable Development in the Postcolonial World (Abingdon, Routledge). https://doi.org/10.4324/9781315211343

Tobin, K. \& Roth, W. (2002), 'The Contradictions in Science Education Peer Review and Possibility for Change', Research in Science Education, 32(3): 269-80. https://doi.org/10.1023/A:1016038414389

UN (United Nations) (2006), Convention on the Rights and Dignity of Persons with Disabilities. www.un.org/disabilities/documents/convention/convoptprot-e.pdf

UN (2015), 2030 Agenda for Sustainable Development. https://www.un.org/sustainabledevelopment/education/

UNESCO (United Nations Educational, Scientific and Cultural Organization) (1990), 'Education For All Goals'. http://www.unesco.org/new/en/education/themes/leading-theinternational-agenda/ education-for-all/efa-goals/

UNESCO (1994), Salamanca Statement and Framework for Action (Paris, UNESCO). https://unesdoc.unesco.org/ark:/48223/pf0000098427

UNESCO (2010), Education For All Global Monitoring Report: Reaching the Marginalized (Paris, UNESCO Publishing).

UNESCO (2016), 'General Comment 4: Article 24: Right to Inclusive Education'. https://www.right-toeducation.org/resource/general-comment-4-article-24-right-inclusive-education

UNESCO (2018), 'Concept Note for the 2020 Global Education Monitoring Report on Inclusion' (Paris, UNESCO). https://unesdoc.unesco.org/ark:/48223/pf0000265329

UNESCO (2020), '2020 GEM Report-Inclusion and Education'. https://en.unesco.org/gem-report/ 
UNESCO Institute for Statistics (2014), 'Global Education Digest: Comparing Education Statistics Across the World'. http://www.uis.unesco.org/Library/Pages/DocumentMorePage.aspx?docId Value $=210 \&$ docIdFld $=1 \mathrm{D}$

UNICEF (United Nations Children's Fund) (2014), 'All Children in School by 2015. Global Initiative on Out-of-school Children' (Regional Report: West and Central Africa; New York, UNICEF).

USAID (United States Agency for International Development) (2003), 'Strengthening Education in the Muslim World'.

www.gaelnet.designs.com/publications/docs/strengtheningeducationinthemuslimworld.pd

Van der Berg, S., Burger, C., Burger, R., Rand, G. du, Gustafsson, M., Moses, E., Shepherd, D., Spaull, N., Taylor, S., Van Broekhuizen, H. \& Von Fintel, D. (2011), 'Low Quality Education as a Poverty Trap', Stellenbosch Economic Working Papers 25/11. https://www.google.com/url?sa=t\&rct=j\&q= \&esrc $=$ s\&source $=$ web $\& c d=1 \& c a d=$ rja $\&$ uact $=8 \&$ ved $=0$ ahUKEwjb8ueKibjUAhXqB8AKHSJQCAMQFggnMAA\&url=https $\% 3 \mathrm{~A} \% 2 \mathrm{~F} \% 2 \mathrm{Fwww}$.ekon.sun.ac.za $\% 2 \mathrm{Fwpapers} \% 2 \mathrm{~F} 2011 \% 2 \mathrm{~F}$ wp252011\%2Fwp-25-2011.pdf\&usg=AFQjCNEX4KWQBR2msRSqiMlcCRSO_F9rpQ\&sig2= R7INQMIqbqQN3_omOFZfVg.

Walton, E. (2011), 'Getting Inclusion Right in South Africa', Intervention in School and Clinic, 46(4): 240-5. https://doi.org/10.1177/1053451210389033

Walton, E. (2015), 'Global Concerns and Local Realities: The "Making Education Inclusive" Conference in Johannesburg', Intervention in School and Clinic, 50(3): 173-7. https://doi.org/10.1177/1053451214542039

Walton, E. (2017), 'Inclusive Education: A Tame Solution to a Wicked Problem?', in N. Phasha, D. Mahlo \& G. Dei (eds) Inclusive Education in African Contexts (Rotterdam, Sense Publishers), 85-100. https://doi.org/10.1007/978-94-6300-803-7_6

Walton, E. (2018), 'Decolonising (Through) Inclusive Education?', Educational Research for Social Change, 7(0): 31-45. https://doi.org/10.17159/2221-4070/2018/v7i0a3

Wright, H.K. (2007), 'Rethinking the Place of African Worldviews and Ways of Knowing in Education', Diaspora Indigenous and Minority Education, 1(4): 243-7. https://doi.org/10.1080/15595690701563956

Young. M. (2009), 'What Are Schools For?', in H. Lauder, J. Porter \& H. Daniels (eds) Knowledge, Values and Educational Policy: Critical Perspectives on Education (Abingdon, Routledge), 10-18.

\section{Notes on the authors}

Dr Hadiza Kere Abdulrahman lectures in Special and Inclusive Education at Bishop Grosseteste University in the UK and is originally from Nigeria. She researches around issues of identity and its constructions in different contexts, especially in the ways that it intersects with various other societal structures. She is also interested in the ways that colonial(ism/ity) shapes the narratives regarding education in postcolonial societies; and especially how it affects people and how they come to 'know' the things they know. She is a passionate advocate for Almajirai. hadiza.abdulrahman@bishopg.ac.uk

Dr Foluke Adebisi is a Senior Lecturer in Law at the University of Bristol in the UK. She has a background in legal practice and NGO work and researches around Africa, African studies, positionality, and the implementation of human rights, education, the higher education structure, intersectionality, equality and diversity, decolonisation 
movements, and critical race theory.

foluke.adebisi@bristol.ac.uk

Dr Zibah Nwako completed her PhD at the University of Bristol in the UK. Her thesis is titled 'In Our Own Voices: A Critical Participatory Study of the Wellbeing of Female Undergraduate Students in Nigeria' and she researched this topic using a postcolonial feminist lens. She is a visiting lecturer and licensed trainer on women's personal development courses and gender justice. Her research interests include the personal welfare and well-being of girls in Africa, non-formal education and lifewide learning, qualitative research methodologies, and creative methods.

zibah.nwako@bristol.ac.uk

Dr Elizabeth Walton is an Associate Professor of Special and Inclusive Education at the University of Nottingham in the UK. Her research interests include teacher education for inclusive teaching, the knowledge of inclusive education, exposing exclusion, and enabling inclusion in education. She is a member of the forum of the UNESCO chair for Teacher Education for Diversity and Development and is a visiting Associate Professor at the Wits School of Education in Johannesburg South Africa.

Elizabeth.Walton@nottingham.ac.uk

To cite the article: Hadiza Kere Abdulrahman, Foluke Adebisi, Zibah Nwako and Elizabeth Walton (2021), 'Revisiting (inclusive) education in the postcolony', Journal of the British Academy, 9(s1): 47-75.

DOI https://doi.org/10.5871/jba/009s1.047

Journal of the British Academy (ISSN 2052-7217) is published by

The British Academy, 10-11 Carlton House Terrace, London, SW1Y 5AH

www.thebritishacademy.ac.uk 
